\title{
A Comparison of The Clinical Characteristics Comprising Abdominal Wall Endometriosis of Various Types
}

\section{YuShi Wu}

PUMCH: Peking Union Medical College Hospital https://orcid.org/0000-0003-0608-4420

\section{Yi Dai}

PUMCH: Peking Union Medical College Hospital

\section{Junji Zhang}

PUMCH: Peking Union Medical College Hospital

\section{Xiaoyan Li}

PUMCH: Peking Union Medical College Hospital

\section{Jinghua Shi}

PUMCH: Peking Union Medical College Hospital https://orcid.org/0000-0001-5267-9092

\section{Zhiyue Gu}

PUMCH: Peking Union Medical College Hospital

Jing Zhang

PUMCH: Peking Union Medical College Hospital

Jinhua Leng ( $\sim$ lengjenny@vip.sina.com )

PUMCH: Peking Union Medical College Hospital https://orcid.org/0000-0001-5604-4019

\section{Research Article}

Keywords: Abdominal wall endometriosis, Clinical characteristics, Classification, Recurrence

Posted Date: August 24th, 2021

DOI: https://doi.org/10.21203/rs.3.rs-601588/v1

License: (1) (1) This work is licensed under a Creative Commons Attribution 4.0 International License. Read Full License 


\section{Abstract \\ Purpose}

To classify abdominal wall endometriosis (AWE) according to the invasive levels of tissue mass, and to compare the differences in clinical characteristics between different types of AWE.

\section{Methods}

In this study, we retrospectively analyzed the clinical data of 367 patients who had undergone resection of abdominal-wall endometriotic lesions at the Peking Union Medical College Hospital from January 2008 to December 2018, and we divided the patients into three types according to their deepest level of lesion invasion. Type I designated invasion of skin and subcutaneous tissue; type II, of fascia and rectus abdominis; and type III, of peritoneum. We classified, compared, and analyzed the general conditions, clinical manifestations, auxiliary examinations, surgical conditions, postoperative conditions, and recurrence status of patients.

\section{Result}

s Of the 367 patients, type I patients accounted for $13.62 \%$, type II patients for $56.68 \%$, and type III for $29.7 \%$. With respect to group comparisons, we observed that as the location of the mass deepened, the rate of concurrent pelvic endometriosis increased $(P=0.007)$, recurrent AWE was augmented $(P=0.02)$, the size of the mass increased $(P<0.001)$, the rate of multiple lesions became elevated $(P<0.001)$, the rate of mesh implantation increased $(P<0.001)$, the length of postoperative hospital stay $(P<0.001)$ was lengthened, the number of postoperative fever cases $(P=0.006)$ increased, and the risk of drainage placement $(P<0.001)$ was enhanced. The 5-year cumulative recurrence rate was $3.3 \%$, and there was no significant difference in the recurrence rate among various types of AWE.

\section{Conclusion}

Various types of AWE manifest different clinical characteristics, surgical options, associations with pelvic endometriosis, and postoperative conditions.

\section{Introduction}

Abdominal wall endometriosis (AWE) is defined as the implantation and embedding of ectopic endometrial tissue into the abdominal wall. The majority of AWE is secondary to the incision of cesarean section, can also be secondary to other gynecologic operations [1], and can invade all layers of the abdominal wall. AWE lesions have been described in relation to the rectus abdominis [2], but there is no 
accurate definition at present. Whether the different layers invaded by the lesions have an impact on surgical methods, surgical results, or chances of recurrence is currently unknown.

We reviewed 367 cases of AWE managed at the Peking Union Medical College Hospital (PUMCH) over a 10-year period and also the current literature. In this study we aimed to assess the differences in demographic and clinical characteristics, surgical options, recurrence rates, and association with pelvic endometriosis in various types of patients with AWE.

\section{Materials And Methods}

\section{Study design and data collection}

This retrospective, observational, descriptive study included a cohort of 367 women who underwent surgery at our institution from January 2008 to December 2018, and who had a confirmed diagnosis of AWE upon histopathology. We reviewed each patient's history, characteristics, clinical presentation, nodule size and location, associated pelvic endometriosis, type of surgery performed, and recurrency.

\section{Surgeries}

For patients with initial onset, the latency period refers to the time from the previous cesarean section or gynecologic operation to the appearance of a mass on the abdominal wall; for patients with recurrence, the incubation period refers to the time after the last resection of the abdominal-wall endometriotic lesion to the reappearance of the mass.

With respect to the surgeries, an incision was made along the original surgical scar and the mass was explored. A cold knife was used to sharply separate the lesion and surrounding normal tissues along the edge of the lesion, and both the AWE mass and the original surgical scar were completely removed. If the lesion invaded the peritoneum or if the preoperative auxiliary examination suggested a concurrent pelvic mass, we then explored the abdominal cavity. If the tissue defect was large, impossible to suture directly, or if the tissue tension was high and the remodeling of the abdominal wall was not ideal, a polypropylene patch was implanted. All patients with patch implantation were placed on subcutaneous drainage, and all underwent compression bandaging of the abdominal wall after surgery. Except for two consecutive measurements on the day of the operation (with an interval of $\geq 4 \mathrm{~h}$ between the two measurements), patients with a temperature $\geq 38.5^{\circ} \mathrm{C}$ were defined as exhibiting postoperative fever [3].

According to the position of the endometriotic mass, patients were divided into 3 types. Type I included AWE with infringement of the skin and adipose layer; type II reflected mass infringement of the fascial rectus abdominis, which can invade the skin and subcutaneous tissue at the same time; and type III showed infringement of the muscle and peritoneum, which can also invade the skin and subcutaneous tissue simultaneously. If the mass invaded multiple layers, it was classified according to the deepest level of its invasion. 
All of the patients were followed up for 2-10 years. During the follow-up period, telephone or outpatient follow-up was conducted every 3-6 months. A painful mass on the abdominal wall found on physical or imaging examination was defined as a clinical recurrence.

\section{Statistical analysis}

Statistical analysis was performed using SPSS 25.0 (SPSS Inc., Chicago, IL, USA). The normality of continuous variables was tested using the Shapiro-Wilk test, and comparisons of normally distributed, continuous data were made with Student's $t$-test. Three sets of non-normally distributed, continuous data were analyzed with the rank-sum test; otherwise, we employed the Kruskal-Wallis $\mathrm{H}$ test. The categorical data were analyzed with $\chi 2$ and the Fisher exact-probability test. The differences were considered statistically significant when the p-value was less than 0.05 .

\section{Results}

We initially provided the locations of the endometriomas to classify the patients and divide them into three groups. Baseline characteristics of the patients are summarized in Table 1. Of 367 patients, there were 50 cases of type I (13.62\%), 208 cases of type II (56.68\%), and 109 cases of type III (29.7\%). Three hundred sixty cases (98.1\%) had a history of cesarean section, and 89 cases $(24.3 \%)$ had a history of other gynecologic operations; with 37 cases $(10.1 \%)$ manifesting a recurrence of AWE. Of these recurrency cases, there were 2 cases (4\%) of type I patients, 17 cases $(8.17 \%)$ of type II, and 18 cases (16.51\%) of type III. The differences among the three types were statistically significant $(P=0.02)$. 
Table 1

Baseline characteristics

\begin{tabular}{|c|c|c|c|c|c|c|c|}
\hline & \multicolumn{2}{|l|}{ Type 1} & \multicolumn{2}{|l|}{ Type 2} & \multicolumn{2}{|l|}{ Type 3} & \multirow[t]{2}{*}{$\mathbf{P}$} \\
\hline & $\begin{array}{l}\text { Mean } \pm \\
\text { SD }\end{array}$ & $\begin{array}{l}\mathrm{N} \\
(\%)\end{array}$ & $\begin{array}{l}\text { Mean } \pm \\
\text { SD }\end{array}$ & $\mathbf{N}(\%)$ & $\begin{array}{l}\text { Mean } \pm \\
\text { SD }\end{array}$ & $N(\%)$ & \\
\hline Patient age (years) & $\begin{array}{l}33.68 \pm \\
4.03\end{array}$ & & $\begin{array}{l}34.08 \pm \\
4.49\end{array}$ & & $\begin{array}{l}35.94 \pm \\
4.34\end{array}$ & & $\begin{array}{l}<.001 \\
0.001\end{array}$ \\
\hline Gestation & $\begin{array}{l}1.82 \pm \\
1.00\end{array}$ & & $\begin{array}{l}1.93 \pm \\
1.19\end{array}$ & & $\begin{array}{l}1.95 \pm \\
1.36\end{array}$ & & 0.803 \\
\hline Parity & $\begin{array}{l}1.18 \pm \\
0.44\end{array}$ & & $\begin{array}{l}1.15 \pm \\
0.46\end{array}$ & & $\begin{array}{l}1.18 \pm \\
0.48\end{array}$ & & 0.836 \\
\hline Cesarean sections & $1.10 \pm 0.3$ & & $\begin{array}{l}1.10 \pm \\
0.30\end{array}$ & & $\begin{array}{l}1.10 \pm \\
0.40\end{array}$ & & 0.455 \\
\hline $\begin{array}{l}\text { Age at menarche } \\
\text { (years) }\end{array}$ & $\begin{array}{l}13.30 \pm \\
1.22\end{array}$ & & $\begin{array}{l}13.50 \pm \\
1.30\end{array}$ & & $\begin{array}{l}13.33 \pm \\
1.26\end{array}$ & & 0.388 \\
\hline Menses (days) & $\begin{array}{l}5.78 \pm \\
1.76\end{array}$ & & $\begin{array}{l}5.98 \pm \\
1.35\end{array}$ & & $\begin{array}{l}5.85 \pm \\
1.37\end{array}$ & & 0.576 \\
\hline $\begin{array}{l}\text { Menstrual cycle } \\
\text { length (days) }\end{array}$ & $\begin{array}{l}28.9 \pm \\
3.00\end{array}$ & & $\begin{array}{l}29.02 \pm \\
3.12\end{array}$ & & $\begin{array}{l}29.35 \pm \\
4.28\end{array}$ & & 0.619 \\
\hline $\begin{array}{l}\text { Latency period } \\
\text { (months) }\end{array}$ & $\begin{array}{l}35.02 \pm \\
34.75\end{array}$ & & $\begin{array}{l}31.08 \pm \\
28.03\end{array}$ & & $\begin{array}{l}38.69 \pm \\
35.41\end{array}$ & & 0.120 \\
\hline $\begin{array}{l}\text { Previous surgery for } \\
\text { AWE (\%) }\end{array}$ & & $\begin{array}{l}2 \\
(4 \%)\end{array}$ & & $\begin{array}{l}17 \\
(8.17 \%)\end{array}$ & & $\begin{array}{l}18 \\
(16.51 \%)\end{array}$ & 0.020 \\
\hline
\end{tabular}

The differences between age and history of previous resection for AWE were statistically significant among the 3 types of AWE. A pairwise comparison among the three types showed that the proportion of type III patients with a history of AWE resection was significantly higher than for the other two types $(\mathrm{P}<$ 0.05).

All patients exhibited a symptom of abdominal wall masses and underwent abdominal wall ultrasonography to measure the lesions before surgery; some of patients also felt abdominal wall pain during menstruation. Abdominal wall pain occurred in 38 cases of type I patients (76\%), 173 cases of type II (83.17\%), and 89 cases of type III (81.65\%). When we compared the maximal ultrasonographic diameters of the three types of patients (type I, $1.8 \pm 0.7 \mathrm{~cm}$; type II, $2.7 \pm 1.2 \mathrm{~cm}$; and type III, $4.0 \pm 1.7$ $\mathrm{cm})$, the differences were statistically significant $(<0.001)$.

All patients had confirmed endometriotic nodules at the abdominal wall that were surgically excised, and 65 patients $(17.7 \%)$ demonstrated concurrent pelvic endometriosis. The average surgical duration was $1.04 \pm 0.45 \mathrm{~h}$, and the average diameter of the lesions removed during the operation was $3.70 \pm 1.72 \mathrm{~cm}$. 
110 patients required primary mesh repair, representing $43.7 \%$ of the 317 women with type II or type III AWE. Patients who had larger resection area and all the patients who had patch placement underwent drainage on the layer of fascia.

Table 2

Surgical data

\begin{tabular}{|c|c|c|c|c|c|c|c|}
\hline & \multicolumn{2}{|l|}{ Type I } & \multicolumn{2}{|l|}{ Type II } & \multicolumn{2}{|c|}{ Type III } & \multirow[t]{2}{*}{$\mathbf{P}$} \\
\hline & $\begin{array}{l}\text { Mean } \\
\pm \text { SD }\end{array}$ & $\mathbf{N}(\%)$ & $\begin{array}{l}\text { Mean } \\
\pm \text { SD }\end{array}$ & $\mathbf{N}(\%)$ & $\begin{array}{l}\text { Mean } \\
\pm \text { SD }\end{array}$ & $\mathbf{N}(\%)$ & \\
\hline $\begin{array}{l}\text { Size of endometriomas } \\
(\mathrm{cm})\end{array}$ & $\begin{array}{l}2.36 \pm \\
0.96\end{array}$ & & $\begin{array}{l}3.35 \pm \\
1.30\end{array}$ & & $\begin{array}{l}4.99 \pm \\
1.89\end{array}$ & & $\dot{0} 001$ \\
\hline $\begin{array}{l}\text { Numbers of multiple } \\
\text { endometriomas }\end{array}$ & & $4(8 \%)$ & & $\begin{array}{l}42 \\
(20.19 \%)\end{array}$ & & $\begin{array}{l}28 \\
(25.69 \%)\end{array}$ & $\begin{array}{l}< \\
0.001\end{array}$ \\
\hline $\begin{array}{l}\text { Concurrence of pelvic } \\
\text { endometriosis }\end{array}$ & & $\begin{array}{l}10 \\
(20 \%)\end{array}$ & & $\begin{array}{l}26 \\
(12.5 \%)\end{array}$ & & $\begin{array}{l}29 \\
(26.61 \%)\end{array}$ & 0.007 \\
\hline Polypropylene mesh & & $0(0 \%)$ & & $\begin{array}{l}38 \\
(18.27 \%)\end{array}$ & & $\begin{array}{l}72 \\
(66.6 \%)\end{array}$ & $\dot{0} 001$ \\
\hline Drainage & & $\begin{array}{l}3 \\
(6.0 \%)\end{array}$ & & $\begin{array}{l}57 \\
(27.5 \%)\end{array}$ & & $\begin{array}{l}77 \\
(70.6 \%)\end{array}$ & $\begin{array}{l}< \\
0.001\end{array}$ \\
\hline Operative time (h) & $\begin{array}{l}0.81 \pm \\
0.29\end{array}$ & & $\begin{array}{l}0.91 \pm \\
0.36\end{array}$ & & $\begin{array}{l}1.38 \pm \\
0.46\end{array}$ & & $\dot{0.001}$ \\
\hline
\end{tabular}

When we compared the different types of patients with pelvic endometriosis, we noted a statistically significant difference $(P=0.007)$. In type III patients, the pelvis was explored during the operation, and 8 cases of pelvic endometriosis were found during the operation-accounting for $27.6 \%$ of the total cases of type III patients with pelvic endometriosis. We also found that the diameter of the lesions and the ratio of multiple lesions in type III patients were significantly greater than the same indices for type I or type II patients; there was also a significant difference in the comparison with type III $(P<0.05)$. Concerning the placement of the patch, the proportion with patch placement in type III patients was significantly higher than that in type II, and the difference was statistically significant $(P<0.05)$. The operative time (duration) for the various types of patients, the deeper the level of lesion invasion, the longer the operative time, and the results between/among the groups were all statistically different $(P<0.001)$.

All patients were pressure bandaged after the operation, the incisions healed at grade $A$, and the wounds healed satisfactorily at the time of discharge. The patient's hospital stay, postoperative fever, and drainage were analyzed in groups, and the results are shown in Table 3. 
Table 3

Postoperative circumstances

\begin{tabular}{|c|c|c|c|c|c|c|c|}
\hline & \multicolumn{2}{|l|}{ Type I } & \multicolumn{2}{|l|}{ Type II } & \multicolumn{2}{|l|}{ Type III } & \multirow[t]{2}{*}{$\mathbf{P}$} \\
\hline & $\begin{array}{l}\text { Mean } \pm \\
\text { SD }\end{array}$ & $\mathbf{N}(\%)$ & $\begin{array}{l}\text { Mean } \pm \\
\text { SD }\end{array}$ & $\mathbf{N}(\%)$ & $\begin{array}{l}\text { Mean } \pm \\
\text { SD }\end{array}$ & $\mathbf{N}(\%)$ & \\
\hline $\begin{array}{l}\text { Hospital stay } \\
\text { (days) }\end{array}$ & $\begin{array}{l}5.58 \pm \\
2.30\end{array}$ & & $\begin{array}{l}5.96 \pm \\
2.65\end{array}$ & & $\begin{array}{l}8.27 \pm \\
2.82\end{array}$ & & $<.001$ \\
\hline $\begin{array}{l}\text { Postoperative } \\
\text { fever }\end{array}$ & & $\begin{array}{l}0 \\
(0.00 \%)\end{array}$ & & $\begin{array}{l}3 \\
(1.44 \%)\end{array}$ & & $\begin{array}{l}8 \\
(7.34 \%)\end{array}$ & 0.006 \\
\hline Temperature $\left({ }^{\circ} \mathrm{C}\right)$ & $\begin{array}{l}37.2 \pm \\
0.40\end{array}$ & & $\begin{array}{l}37.1 \pm \\
0.30\end{array}$ & & $\begin{array}{l}37.4 \pm \\
0.40\end{array}$ & & $<.001$ \\
\hline
\end{tabular}

With the deepening of the endometriotic invasion, the proportion of patients with postoperative fever gradually increased $(P=0.006)$, and the length of hospital stay was significantly prolonged $(P<0.001)$. The patients were followed up for 24-120 months, with an average follow-up time of $43.95 \pm 20.94$ months and a median follow-up time of 41 months. We followed 308 cases, and 8 cases were diagnosed. The 5-year cumulative recurrence rate was 3.3\%. The 5-year cumulative recurrence rate for type I was $4 \%$, type II was $3.3 \%$, and type III was $4.3 \%$ (rates were not statistically significant from one another).

\section{Discussion}

Abdominal wall endometriosis (AWE) is a rare type of endometriosis, with a reported incidence of 0.03$0.4 \%[4,5]$. AWE results from a variety of obstetric and gynecologic surgeries, the majority of which are caesarean sections. The increasing number of caesarean sections and laparotomies are thus expected to increase the rate of AWE $[6,7]$. Surgery is the only curative therapy, and the removal of the lump also causes the chronic pain to disappear. During surgery, the different structures of the abdominal wall should be repaired in layers, and meshes should be inserted if necessary[8]. The anatomical levels of the abdominal wall are skin, subcutaneous fat, anterior rectus abdominis sheath, rectus abdominis, posterior rectus abdominis sheath, and peritoneum from outside to inside [9]. The lesions of abdominal wall endometriosis can invade all these layers, but we do not yet appreciate whether the layers invaded by the lesions impact basic clinical characters, the difficulty of surgery, or postoperative recovery, as there are no extant relevant studies. In this study we collected clinical data from 367 AWE patients who underwent operations at the Peking Union Medical College Hospital over the past 10 years, and compared them according to the level of tissue invasion.

The clinical triangle includes cyclical pain, a lump at the abdominal wall, and a history of caesarean section or similar gynecologic procedures [10]. Local pain at the incision site of the abdominal wall during menstruation has been reported to be the most common complaint, but not all patients manifest painful symptoms related to the menstrual cycle [11, 12]; on rare occasions, a patient presents with skin changes [13]. In our study, the preponderance of cases had a history of caesarean section (98.1\%), all 
patients complained of abdominal wall masses (but not all patients had abdominal wall pain), and the relationship between pain and menstruation was unclear in some patients. Although there was no statistical difference among the three types of patients in latency period, latency for type III showed a tendency to be longer than that for other two types. Presumably because of the deeper location, the time needed to palpate the lesion and until the appearance of pain symptoms was delayed. We did, however, observe significant differences in the previous AWE resection of type III patients, and the proportion of relapsed type III patients was significantly higher than for types I or II. This shows that with deepening lesion invasion, there was a gradual increase in the risk of AWE recurrence.

Various rates for concurrent pelvic endometriosis have been reported in patients with AWE, ranging from $5.3-34 \%$ [14-16], which is similar to our results (17.7\%). However, investigators have not previously analyzed these rates according to differing invasion layers. Our group analysis showed that the rate of concurrent pelvic endometriosis for type III was significantly higher than for the other two types. Among the 29 type III patients with pelvic endometriosis, 8 cases (27.6\%) were found during intraoperative exploration. These data suggest that some patients who may have concurrent pelvic endometriosis cannot be diagnosed by auxiliary examination before surgery, and that the incidence of pelvic endometriosis concurrency may be underestimated. Because all type III patients underwent pelvic exploration during the surgical procedure, endometriomas that are typically difficult to uncover by imaging could then be located. This suggests that before surgery, clinicians should not only assess the level of invasion of intra-abdominal endometriotic lesions, but to also complete an assessment of whether the pelvic cavity is associated with the endometriosis; and if necessary, perform intraoperative treatment simultaneously. As we stated, AWE is principally secondary to caesarean section, and most authors have concluded that this rate is comparable to the rate of classical endometriosis in the general population and thus not relevant; however, it is very likely to be underestimated. Therefore, if endometriosis is found during caesarean section, more attention should be paid to the protection and cleaning of the caesarean section incision so as to reduce the risk of implanting the abdominal wall with endometrial fragments.

AWE masses are surrounded by connective tissue, and it is thus difficult for drugs to enter the lesion location, making the drug treatment ineffective. Surgical resection is therefore the primary treatment modality $[17,18]$. By comparing the three types of patients, we found that the deeper the level of invasion, the larger the diameter of the lesion during resection and the higher the risk of multiple lesions. This indicates that the deeper layers of the abdominal wall might be more favorable to the implantation and proliferation of the residual endometrial cells, which is not easy to diagnose early. We suggest two possible causes for the role of different invasion layers. First, the deep layer renders tissue irrigation difficult and induces much more endometrial cell contamination [19]. The second cause is a larger nutrient supply. Endometrial cells require an adequate blood supply to survive in their ectopic sites, and angiogenesis plays an important role in the pathogenesis of endometriosis [20]. Therefore, an enhanced blood supply would provide a relatively rich nutritional environment for the implantation and growth of residual endometrial cells, favoring the occurrence of AWE. For surgical patients, the location and diameter of the removed lesions are closely related to their intraoperative and postoperative treatment 
and prognosis. Intraoperative patch placement was concentrated in our type II and type III patients, and with the deepening of the level of lesion invasion, the proportion of patch placements in type III patients was significantly greater than for type II patients. The probability of drainage also gradually increased, the surgical duration was significantly prolonged, the likelihood of postoperative fever increased, and the length of hospital stay was correspondingly prolonged. Previous studies have confirmed that the size of the lesion is an independent risk factor for patch placement [21], and we herein confirmed that the level of lesion invasion also affected the placement of the patch. The level of lesion invasion thus exerts an impact on the difficulty of surgery and postoperative recovery.

Investigators have previously demonstrated that the recurrence rate of AWE is $4.3-11.4 \%$ [16,22-23], but there are no studies as yet in which comparisons were made between different types of AWE. In our study, the 5-year cumulative recurrence rate was 3.3\%, and most of the recurrence sites were located in the fascia and rectus abdominis. With deeper lesion invasion, the risk of recurrence gradually increased, which may be due to the abundant blood supply in this area-providing a favorable environment for the implantation and continuous growth of the ectopic endometrium. Recurrence may also be due to a deeper location, accompanied by satellite lesions that were not visible to the naked eye, resulting in incomplete removal.

\section{Conclusions}

The most comprehensive treatment used currently for patients with AWE is surgical removal of the lesion. We noted that the level of lesion invasion exerts an important influence on whether the lesion can be removed and the abdominal wall layer repaired. The classification of AWE according to the level of lesion invasion can assist in predicting the difficulty of surgery, the placement of intraoperative patches, postoperative recovery, and recurrence.

\section{Declarations}

\section{Acknowledgements}

None

\section{Funding}

The study is funded by National Key R\&D Program (Grant Number: 2017YFC1001200).

\section{Affiliations}

Department of Obstetrics and Gynecology, Peking Union Medical College Hospital, Peking Union Medical College \& Chinese Academy of Medical Science, Shuaifuyuan No. 1, Dongcheng District, Beijing, 100730, China

Yushi Wu, Yi Dai, Junji Zhang, Xiaoyan Li, Jinghua Shi, Zhiyue Gu, Jing Zhang, \& Jinhua Leng 


\section{Author Contribution}

All authors contributed to the study conception and design. Material preparation, data collection were completed by YW, ZG and JZ. Data analysis were performed by YW. The first draft of the manuscript was written by $Y W$ and $Y D$, and all authors commented on previous versions of the manuscript. All authors approved publication of the final version.

\section{Corresponding author}

Correspondence to Jinhua Leng.

\section{Conflicts of interest}

The authors declare that they have no conflict of interests.

\section{Code availability}

Not applicable.

\section{Ethics approval}

This study was approved by the Ethics Committee of Peking Union Medical College Hospital. 『lRB No. JS1532区

\section{References}

1. Horton JD, Dezee KJ, Ahnfeldt EP, Wagner M. (2008) Abdominal wall endometriosis: a surgeon's perspective and review of 445 cases. Surg 196(2):207.

2. Goker A, Sarsmaz K, Pekindil G, Kandiloglu AR, Kuscu NK. (2014) Rectus abdominis muscle endometriosis. Coll Physicians Surg Pak. 24(12):944-6.

3. Schwandt A, Andrews SJ, Fanning J. (2001)Prospective analysis of a fever evaluation algorithm after major gynecologic surgery. Am J Obstet Gynecol. 184(6):1066-7.

4. Oh EM, Lee WS, Kang JM, Choi ST, Kim KK, Lee WK. (2014) A Surgeon's Perspective of Abdominal Wall Endometriosis at a Caesarean Section Incision: Nine Cases in a Single Institution. Surg Res Pract. 765372.

5. Carsote M, Terzea DC, Valea A, Gheorghisan-Galateanu AA. (2020) Abdominal wall endometriosis (a narrative review). Int J Med Sci. 17(4):536-542.

6. Carsote M, Terzea DC, Valea A, Gheorghisan-Galateanu AA. (2020)Abdominal wall endometriosis (a narrative review). Int J Med Sci. 10;17(4):536-542.

7. Khan Z, Zanfagnin V, El-Nashar SA, Famuyide AO, Daftary GS, Hopkins MR. (2017) Risk Factors, Clinical Presentation, and Outcomes for Abdominal Wall Endometriosis. J Minim Invasive Gynecol. 24(3):478-484. 
8. Blanco RG, Parithivel VS, Shah AK, Gumbs MA, Schein M, Gerst PH. (2003) Abdominal wall endometriomas. Am J Surg. 185(6):596-8.

9. Hellinger A, Roth I, Biber FC, Frenken M, Witzleb S, Lammers BJ. Chirurgische Anatomie der Bauchdecke(2016) Surgical anatomy of the abdominal wall. Chirurg. 87(9):724-730.

10. Tatli F, Gozeneli O, Uyanikoglu H, Uzunkoy A, Yalcın HC, Ozgonul A, Bardakci O, Incebiyik A, Guldur ME. (2018)The clinical characteristics and surgical approach of scar endometriosis: A case series of 14 women. Bosn J Basic Med Sci. 1;18(3):275-278.

11. Dwivedi AJ,Agrawal SN,Silva YJ. (2002) Abdominal wall endometriomas .Dig Dis Sci, 47(2):456.

12. Zhang P, Sun Y, Zhang C, Yang Y, Zhang L, Wang N, Xu H. (2019) Cesarean scar endometriosis: presentation of 198 cases and literature review. BMC Womens Health. 18;19(1):14.

13. Alnafisah F, Dawa SK, Alalfy S. (2018) Skin Endometriosis at the Caesarean Section Scar: A Case Report and Review of the Literature. Cureus. Jan 13;10(1):e2063.

14. Ding Y, Zhu J. (2013) A retrospective review of abdominal wall endometriosis in Shanghai, China. Int J Gynaecol Obstet. 121(1):41 - 4.

15. Sumathy S, Mangalakanthi J, Purushothaman K, Sharma D, Remadevi C, Sreedhar S. (2017) Symptomatology and Surgical Perspective of Scar Endometriosis: A Case Series of 16 Women. J Obstet Gynaecol India. 67(3):218-223.

16. Horton JD, Dezee KJ, Ahnfeldt EP, Wagner M. (2008) Abdominal wall endometriosis: a surgeon's perspective and review of 445 cases. Am J Surg. 196(2):207 - 12.

17. Pas K, Joanna SM, Renata R, Skręt A, Barnaś E. (2008) Prospective study concerning 71 cases of caesarean scar endometriosis (CSE). J Obstet Gynaecol. 37(6):775-778.

18. Ozturk A, Kaya C, Bozkurtoglu H, Tan N, Yananli ZD, Ucmakli E. (2016) Scar Endometrioma: An Uncommon Yet Easily Treated Condition. J Reprod Med. 61(5-6):249 - 53.

19. Mathai M, Hofmeyr GJ. (2007) Abdominal surgical incisions for caesarean section. Cochrane Database Syst Rev. 24;(1)

20. McLaren J. (2000). Vascular endothelial growth factor and endometriotic angiogenesis. Human reproduction update, $6(1)$, 45-55.

21. Deng S, Leng J H, Lang J H. (2013)The Feasibility of Preoperative Prediction for Fascia Defect Needing Mesh Repair in Patients with Abdominal Wall Endometriosis[J]. Journal of International Obstetrics and Gynecology, (04):88-92.

22. Marras S, Pluchino N, Petignat P, Wenger JM, Ris F, Buchs NC, Dubuisson J. (2019) Abdominal wall endometriosis: An 11-year retrospective observational cohort study. Eur J Obstet Gynecol Reprod Biol X. 16;4:100096.

23. Lopez-Soto A, Sanchez-Zapata MI, Martinez-Cendan JP, Ortiz Reina S, Bernal Mañas CM, Remezal Solano M. (2018) Cutaneous endometriosis: Presentation of 33 cases and literature review. Eur J Obstet Gynecol Reprod Biol. 221:58-63. 